\title{
Sampling Survey of Studying Knowledge, and Attitudes for Cholera Disease in Suq-Al-Sheeuq Residents
}

\author{
Abdulkhaleq A. Ali Ghalib Al-Naqeeb
}

Mohammad E. Abdulsatar

\begin{abstract}
:
Aims: This study aimed to identify level of knowledge, and attitudes concerning Cholera disease among population of Suq-Al-Sheeuq residents, and to find out association between an overall assessment concerning knowledge \& attitudes in light of studies related of socio-demographic characteristics variables, as well as some of general information variables.

Methods: A convenient cross sectional design of sample size (110) persons were selected from Suq-Al-Sheeuq residents, during the period from 1/10/2015 to $1 / 11 / 2015$,majority of collected samples were from male, and they are accounted $80(72.7 \%)$. The results of the review of the questionnaire by the experts revealed that all of the experts agreed that (60) items of the questionnaire distributed by different main domains, such that knowledge, and attitudes contents (51), and (9) items respectively, which were clear and adequate for the measurement of this study, pilot study of (10) persons proved high levels of reliability of inter and intra examiners, as well as internal consistency shows that designed questionnaire were valid to study the phenomenon on the same population at any time in the future.

Results: This research shows moderate of knowledge concerning cholera disease are presented in the studied sample's persons, as well as results shows that most items of attitudes are reported good assessments as a result of applying suggested questionnaire. In addition to that weak relationships with no significant at $\mathrm{P}>0.05$ between studying "knowledge, and attitude" are accounted rather than differences among their sociocharacteristics variables, and weak relationships with no significant at $\mathrm{P}>0.05$, except distribution of source of water.

Conclusions: Among the main conclusions, the studied responding concerning knowledge, and attitudes regarding to general information variables, such that (sources of water, and methods of waste disposal) had a weak relationships, except the distribution of source of water, which representative that persons consumption water "Liquefaction" are accounted better responding than other consumption's sources. As well as, moderate degree of knowledge concerning cholera disease are presented in this study, as well as most of the studied persons had good attitudes concerning cholera disease, which could be interpreting hereditary of life style standby that level indeed.
\end{abstract}

Key words: Cholera Disease, Knowledge \& Attitudes concerning Cholera Disease, Environment Information concerning Cholera Disease, Sources of water and Cholera disease, Methods of waste disposal and Cholera disease.

1.Introduction: Cholera disease is an endemic in Asia, from (1817 - 1923) there were six pandemic waves which are moved through Asia then through the Americas and Africa [1-3].

Iraq is at risk of an epidemics spreading from neighboring countries 
because it lies on the routes of pilgrimage to Mecca and contains a number of holy shrines. During the epidemic of 1820 , when cholera first spread to Basra, there were a great number of deaths and many sectors of the city were completely depopulated [12]. The disease spread to Baghdad, with similar consequences. After that, cholera continued to appear in several epidemic forms during the years 1871, 1889, 1894, 1899 and 1917[13], after which the disease completely disappeared from Iraq to reappear again in August 1966 as a part of the 7th pandemic spread[1-4]. After subsidence of the $7^{\text {th }}$ pandemic in Iraq, occasional outbreaks of cholera continued in Iraq. Recent outbreaks that occur in Iraq during August - October 2008 - As of 29 October 2008, a total of 644 laboratoryconfirmed cholera cases, including eight deaths, had been verified in Iraq [15].

We can say cholera remains a trouble in Iraq, and according to published statistics in October 12, 2015, the number of cholera cases are registered to 1,263 cases[1]. The cases were accounted from at least 15 governorates of the country - Including Babylon (469) cases, Baghdad (304 cases), Qadisiyyah (146 cases), Muthanna (155 cases), Basra (61 cases), Wassit (41) cases, Karbala (33) case, Najaf (32) cases, Thi-Qar(6) cases, Maysan (6) cases, Diyala (2) cases, Duhok (2) cases, Erbil (2) cases, Kirkuk (2) cases, Salah Al-Din (1) case, and Suleimaniyah (1) case [5].

The geographical, social, economic and socio-cultural backgrounds of the population in the affected area that affect practices can also contribute to the spread of cholera. These included low educational levels, practices of handling unhealthy foods and their proximity to surface water. This is due to the fact that bacteria (cholera infection) that cause cholera is known to ordinary population of surface water [5].
As urbanization increases, cholera will be a growing problem in the future as sanitation and water safety are inadequate. Attitudes and practices concerning people's awareness of cholera outbreaks are important for planning preventive health education programs. Cholera control is much cheaper and effective through a preventive strategy than the single therapeutic one. This study aimed to assess knowledge, attitudes and practices that affect cholera outbreaks in the Suq-Al-Sheeuq residents. In the case of appropriate health policies, plans and programs, further formative information is required.

\section{Aims of the Study:}

1.To studying knowledge, attitudes of Cholera disease among a sample inSuqAl-Sheeuq residents.

2.To identify level of knowledge concerning Cholera disease among public of Suq-Al-Sheeuq residents.

3.To identify level of attitude concerning Cholera disease among public of SuqAl-Sheeuq residents.

4.To find out association between overall of studied main domains concerning knowledge \& attitudes in light of studied related of socio-demographical characteristics variables, as well as some of general information variables.

\section{Methodology:}

Design of the study: Cross-sectional design of convenient random sampling technique. The place of data where collection of studied persons were from Suq-Al-Sheeuq Residents randomly of sample size of (110) which were selected randomly.The data were carried out through designed questionnaire including of four parts (socio-demographical characteristics, environment information, knowledge, and attitudes) for Cholera disease. Main 
domains included (60) items distributed by different main domains, knowledge, and attitudes contenting (51), and (9) items respectively, which were established for the first time, and it was cleared and adequate for the measurement of this study throughout supporting and corroboration of experts in the pilot study.

\subsection{Reliability of pilot study}

A convenient sample of ten persons were selected randomly. Table (2-1) showed estimation of reliability coefficients of pilot study, this results shows that intra examiner (test \& pretest), and inter examiners recorded highly and adequate outcomes, throughout through using Al-Naqeeb Formula [6]:

Table (3-1): Reliability Coefficients of the Pilot Study

\begin{tabular}{|c|c|}
\hline Reliability Coefficients & Actual values \\
\hline Inter Examiners & $0.824(42: 510)$ \\
\hline Intra Examiner & $0.940(25: 510)$ \\
\hline
\end{tabular}

\subsection{Reliability of the questionnaire:}

Internal consistency was calculated by using: Alpha Cronbach, as shown in table (2-2), the internal consistency in light of responses is successful, all these means that designed questionnaire were valid to study the phenomenon on the same population at any time in the future.

Table (3-2) : Reliability Coefficients of the Studied Questionnaire's for who had overweigh and obesity

\begin{tabular}{|c|c|c|c|c|}
\hline Reliability Coefficients & Questionnaire & $\begin{array}{c}\text { Standard } \\
\text { lower bound }\end{array}$ & $\begin{array}{c}\text { Actual } \\
\text { values }\end{array}$ & Assessment \\
\hline Methods of Reliability & $\begin{array}{c}\text { Alpha } \\
\text { (Cronbach) }\end{array}$ & $\mathbf{0 . 7 0}$ & $\mathbf{0 . 8 0 8 1}$ & Pass \\
\hline
\end{tabular}

\subsection{Statistical analysis methods}

Statistical data analysis approaches were used in order to analyze and assess results of this study which classified in two parts, descriptive statistics, such that [Tables ( Frequencies, Percentages), Association tables, and graphical presentation throughout using cluster bar chart], and inferential statistics, such that [Chi-Square test for testing the independency, Binomial test for testing two categories nominal scale, contingency coefficients for estimating relationshipsof the association tables.

\section{Results and Findings:}

\section{Part 1: Distribution of Demographical Characteristics variables (SDCv.):}

Table (4-1) shows distribution of "demographical characteristics variables" (DCv.) with comparisons significant, for exploring behavior of elementary parameters either randomly or not randomly distributed comparing with their an expected outcomes. 
Table (4-1): Socio-Demographical Characteristics variables with comparisons significant

\begin{tabular}{|c|c|c|c|c|}
\hline General Information & Classes & No. & $\%$ & $\begin{array}{c}\text { C.S. }{ }^{(*)} \\
\text { P-value }\end{array}$ \\
\hline \multirow{6}{*}{$\begin{array}{c}\text { Age Groups } \\
\text { Yrs. }\end{array}$} & $<20$ yrs. & 4 & 3.6 & \multirow{6}{*}{$\begin{array}{c}\chi^{2}=23.36 \\
\mathbf{P}=0.000 \\
\text { HS }\end{array}$} \\
\hline & $20 \_29$ & 33 & 30 & \\
\hline & $30 \_39$ & 30 & 27.3 & \\
\hline & $40 \_49$ & 23 & 20.9 & \\
\hline & $\geq 50$ yrs. & 20 & 18.2 & \\
\hline & Mean \pm SD & \multicolumn{2}{|c|}{$36.11 \pm 11.55$ yrs. } & \\
\hline \multirow[t]{2}{*}{ Gender } & Male & 80 & 72.7 & \multirow{2}{*}{$\begin{array}{c}\text { Bin. test } \\
\mathbf{P}=0.000 \\
\quad(\mathrm{HS})\end{array}$} \\
\hline & Female & 30 & 27.3 & \\
\hline \multirow[t]{7}{*}{ Education Level } & Illiterate & 7 & 6.4 & \multirow{7}{*}{$\begin{array}{c}\chi^{2}=36.36 \\
P=0.000 \\
\text { HS }\end{array}$} \\
\hline & Read \& write & 7 & 6.4 & \\
\hline & Primary & 10 & 9.1 & \\
\hline & Intermediate & 21 & 19.1 & \\
\hline & Secondary & 19 & $\mathbf{1 7 . 3}$ & \\
\hline & Institute and College & 34 & 30.9 & \\
\hline & College or more & 12 & 10.9 & \\
\hline \multirow[t]{5}{*}{ Occupational } & Government Employee & 66 & 60 & \multirow{5}{*}{$\begin{array}{c}\chi^{2}=120.64 \\
P=0.000 \\
\text { HS }\end{array}$} \\
\hline & Earner & 23 & 20.9 & \\
\hline & Retired & 11 & 10 & \\
\hline & Not Employee & 8 & 7.3 & \\
\hline & Others & 2 & 1.8 & \\
\hline \multirow[t]{3}{*}{ Monthly Income } & Enough & 32 & 29.1 & \multirow{3}{*}{$\begin{array}{c}\chi^{2}=8.745 \\
P=0.013 \\
S\end{array}$} \\
\hline & Not Enough & 51 & 46.4 & \\
\hline & Barely Enough & 27 & 24.5 & \\
\hline \multirow[t]{4}{*}{ Marital Status } & Single & 21 & 19.1 & \multirow{4}{*}{$\begin{array}{c}\chi^{2}=15.1 .46 \\
P=0.000 \\
\text { HS }\end{array}$} \\
\hline & Married & 82 & 74.5 & \\
\hline & Divorced & 4 & 3.6 & \\
\hline & Widowed & 3 & 2.7 & \\
\hline \multirow[t]{2}{*}{ Family Type } & Single & 35 & 31.8 & \multirow{2}{*}{$\begin{array}{c}\text { Bin. test } \\
\begin{array}{c}P=0.000 \\
(H S)\end{array}\end{array}$} \\
\hline & Extended & 75 & 68.2 & \\
\hline \multirow[t]{2}{*}{ Residency } & Rural & 44 & 40 & \multirow{2}{*}{$\begin{array}{c}\text { Bin. test } \\
\begin{array}{c}\mathrm{P}=0.000 \\
\text { (HS) }\end{array}\end{array}$} \\
\hline & Urban & 66 & 60 & \\
\hline \multirow[t]{3}{*}{ Socio-Economic Status } & < 59 "Low" & 37 & 33.6 & \multirow{3}{*}{$\begin{array}{c}\chi^{2}=221.53 \\
P=0.000 \\
\text { HS }\end{array}$} \\
\hline & 60 _80 "Mod." & 55 & 50 & \\
\hline & 81 _ 100 "High" & 18 & 16.4 & \\
\hline
\end{tabular}

${ }^{(*)}$ HS: Highly Sig. at $\mathrm{P}<0.01$; S: Sig. at $\mathrm{P}<0.05$; NS: Non Sig. at $\mathrm{P}>0.05$; Testing of random distribution are based on (Chi-Square \&Bin: Binomial tests).

Results shows that all studied (SDCv.) had reported highly significant differences at $\mathrm{P}<0.01$, as well as monthly income, are accounted a significant different at $\mathrm{P}<0.05$. It could be conclude that most of the studied persons were recorded "Low \& Moderate" levels, and they are accounted 92(83.6\%), Appendix (A). 


\section{Part 2: Distribution of Environment Information (EI):}

Table (4-2) shows distribution of the "Environment Information", variables with comparison significant.

Table (4-2): Descriptive Statistics of studied Environment Information for studied sample

\begin{tabular}{|c|c|c|c|c|}
\hline $\begin{array}{l}\text { General Information } \\
\text { "Environment" }\end{array}$ & Classes & No. & $\%$ & $\begin{array}{l}\text { C.S. }{ }^{(*)} \\
\text { P-value }\end{array}$ \\
\hline \multirow[t]{6}{*}{ Source of water } & Liquefaction of water & 76 & 69.1 & \multirow{6}{*}{$\begin{array}{c}\chi^{2}=221.53 \\
\text { P=0.000 } \\
\text { HS }\end{array}$} \\
\hline & Canals & 8 & 7.3 & \\
\hline & Well & 1 & 0.9 & \\
\hline & Bottled & 4 & 3.6 & \\
\hline & Reservoirs water & 10 & 9.1 & \\
\hline & River water & 11 & 10 & \\
\hline \multirow[t]{2}{*}{ Method of waste disposal } & Sewerage & 41 & 37.3 & \multirow{2}{*}{$\begin{array}{c}\text { Bin. test } \\
\mathbf{P}=\mathbf{0 . 0 1 0}(\mathrm{S})\end{array}$} \\
\hline & Sabtatink & 69 & 62.7 & \\
\hline
\end{tabular}

${ }^{(*)}$ HS: Highly Sig. at $\mathbf{P}<0.01$; S: Sig. at $\mathbf{P}<0.05$; Testing of random distribution are based on (Chi-Square \&Bin: Binomial tests).

Results shows that vast majority of studied sample had consumption of Liquefaction water, and accounted for 76(69.1\%), and reported highly significant different compared with others sources at $\mathrm{P}<0.01$.

With respect to subjects "method of waste disposal", most of studied individuals are used dejection tank, which is known "Sabtatink" at their houses, and they are accounted 69(62.7\%), with significant different compared with other source at $\mathrm{P}<0.05$.

\section{Part 3: Knowledge \& Attitudes for Cholera disease:}

Summary statistics of studied questionnaire concerning Knowledge for Cholera disease are illustrated in appendix (B).

Knowledge part consists of 51 items, distributed among 12 main domains, such that (Cholera definition, mode of transmissions, sing of disease, diagnosis of cholera throughout:, costive agent of disease, how can the prevention of cholera, infect Cholera, Treatment, the most important complications of the disease, what are the most important things to be observed for the traveler to affected areas should, increasing susceptibility at:, and what do you think is the most roads contribute to the transmission of the disease), which consists of 4, 6, 6, 3, 3, 6, 3, 5, 4, 3, 4, and 4 items which are associated of sub domains in light of knowledge's main domain respectively.

Results shows that most items of knowledge main domain had reported moderate assessments, resultedby applying the suggested questionnaire, and they are accounted $31(60.78 \%)$ items, as well as a few items that are reported low assessments, and accounted $4(7.84 \%$ ) items, such that (feeling very thirsty as a result of the constant diarrhea and vomiting, children infected only, elderly and individuals infected with low acidity), while leftover items are recorded high grads of assessments, and they are accounted 16(31.37\%) items.

Summary statistics of studied questionnaire concerning attitudes for Cholera disease are illustrated in appendix (C).Attitude part consists of 9 items, which had recorded highly grads of assessments, as well as only (6.7\%) percent of that information are decayed indeed. 
Table (4-3-3): Summary Statistics of the studied sub \& main domains of questions concerning knowledge \& attitudes for Cholera disease

\begin{tabular}{|c|c|c|c|c|}
\hline Sub \& Main Domains & GMS & $\mathrm{SD}$ & RS\% & A.D. \\
\hline Cholera definition & 0.700 & 0.338 & 70.0 & $\mathbf{H}$ \\
\hline Mode of transmissions & 0.709 & 0.221 & 70.9 & $\mathbf{H}$ \\
\hline Sings of disease & 0.596 & 0.214 & 59.6 & $\mathbf{M}$ \\
\hline Diagnosis of cholera throughout: & 0.630 & 0.385 & 63.0 & $\mathbf{M}$ \\
\hline Costive agent of disease & 0.645 & 0.357 & 64.5 & $\mathbf{M}$ \\
\hline How can the prevention of cholera & 0.670 & 0.320 & 67.0 & M \\
\hline Infect cholera & 0.401 & 0.236 & 40.1 & $\mathbf{M}$ \\
\hline Treatment & 0.638 & 0.207 & 63.8 & $\mathbf{M}$ \\
\hline $\begin{array}{c}\text { The most important complications of the } \\
\text { disease }\end{array}$ & 0.661 & 0.246 & 66.1 & $\mathbf{M}$ \\
\hline $\begin{array}{l}\text { What are the most important things to be } \\
\text { observed for the traveler to affected areas } \\
\text { should }\end{array}$ & 0.586 & 0.265 & 58.6 & $\mathbf{M}$ \\
\hline Increasing susceptibility at & 0.541 & 0.243 & 54.1 & M \\
\hline $\begin{array}{l}\text { What do you think is the most roads } \\
\text { contribute to the transmission of the disease }\end{array}$ & 0.498 & 0.238 & 49.8 & $\mathbf{M}$ \\
\hline Overall Knowledge & 0.606 & 0.1328 & 61.5 & M \\
\hline Attitudes for Cholera disease & 1.197 & 0.275 & 93.3 & $\mathbf{H}$ \\
\hline
\end{tabular}

(A.D.): Assessment Degree, with Scoring Scales: [(0 - 33.33); (33.34 - 66.66); (66.67 - 100)] L: Low; M:Moderate; and H:High respectively; GMS: Grand mean of score; SD: Standard deviation; RS: Relative Sufficiency

\section{Part 4: Relationship between some related variables and Studied Main Domains:}

Table (4-4-1) shows relationships between (SDCv. and Studied Main Domains) according to contingency correlation coefficients. Results shows that association between impact of studied responding concerning knowledge, and attitude in light of distribution of SDCv. had weak relationships with no significant at $\mathrm{P}>0.05$. Accordance with preceding results, it could be conclude that studied questionnaire of studying "Impact of knowledge, and attitudes" could be amended for studied population rather than presents differences among their SDCv. 
Table (4-4-1): Relationship between studied domains (knowledge main \& attitudes) in light of studied DCv. with comparisons significant

\begin{tabular}{|c|c|c|c|c|c|}
\hline Related Variables & value & Knowledge & C.S. & Attitude & C.S. ${ }^{(*)}$ \\
\hline \multirow[t]{2}{*}{ Age Groups } & C.C. & 0.123 & \multirow[t]{2}{*}{ NS } & 0.178 & \multirow[t]{2}{*}{ NS } \\
\hline & P-value & 0.792 & & 0.466 & \\
\hline \multirow[t]{2}{*}{ Gender } & C.C. & 0.064 & \multirow[t]{2}{*}{ NS } & 0.023 & \multirow[t]{2}{*}{ NS } \\
\hline & P-value & 0.503 & & 0.811 & \\
\hline \multirow[t]{2}{*}{ Education Level } & C.C. & 0.144 & \multirow[t]{2}{*}{ NS } & 0.167 & \multirow[t]{2}{*}{ NS } \\
\hline & P-value & 0.887 & & 0.790 & \\
\hline \multirow[t]{2}{*}{ Occupation } & C.C. & 0.093 & \multirow[t]{2}{*}{ NS } & 0.087 & \multirow[t]{2}{*}{ NS } \\
\hline & P-value & 0.915 & & 0.933 & \\
\hline \multirow[t]{2}{*}{ Monthly Income } & C.C. & 0.093 & \multirow[t]{2}{*}{ NS } & 0.169 & \multirow[t]{2}{*}{ NS } \\
\hline & P-value & 0.617 & & 0.198 & \\
\hline \multirow[t]{2}{*}{ Marital Status } & C.C. & 0.058 & \multirow[t]{2}{*}{ NS } & 0.097 & \multirow[t]{2}{*}{ NS } \\
\hline & P-value & 0.947 & & 0.788 & \\
\hline \multirow[t]{2}{*}{ Family Type } & C.C. & 0.015 & \multirow[t]{2}{*}{ NS } & 0.124 & \multirow[t]{2}{*}{ NS } \\
\hline & P-value & 0.873 & & 0.189 & \\
\hline \multirow[t]{2}{*}{ Residency } & C.C. & 0.127 & \multirow[t]{2}{*}{ NS } & 0.023 & \multirow[t]{2}{*}{ NS } \\
\hline & P-value & 0.180 & & 0.811 & \\
\hline \multirow[t]{2}{*}{ Socio-Economic Status } & C.C. & 0.069 & \multirow[t]{2}{*}{ NS } & 0.227 & \multirow[t]{2}{*}{ NS } \\
\hline & P-value & 0.768 & & 0.0503 & \\
\hline
\end{tabular}

${ }^{(*)}$ NS: Non Sig. at P>0.05; Test Statistics are based on ( CC; Contingency Coefficient test).

Table (4-4-2) shows relationships between [(GIv.), and Studied Main Domains] according to contingency correlation coefficients. Results shows association between impact of studied responding concerning knowledge, and attitude in light of distribution of GIv. had weak relationships with no significant at $\mathrm{P}>0.05$, except distribution of source of water, which representative that individuals of consumption water of "Liquefaction" source are accounted better responding than other consumption's sources. As well as figure (4-4) represent the preceding distributions.

Table (4-4-2): Relationship between (Knowledge \& Attitudes) in related to General Information variables with comparisons significant

\begin{tabular}{|c|c|c|c|c|c|}
\hline $\begin{array}{c}\text { General } \\
\text { Information } \\
\text { variables }\end{array}$ & value & Knowledge & C.S. & Attitude & \multirow{2}{*}{ C.S. ${ }^{(*)}$} \\
\hline Source of water & C.C. & $\mathbf{0 . 3 4 6}$ & S & $\mathbf{0 . 1 4 4}$ & NS \\
\cline { 2 - 3 } & P-value & $\mathbf{0 . 0 1 1}$ & & $\mathbf{0 . 8 0 2}$ & \\
\hline $\begin{array}{c}\text { Method of waste } \\
\text { disposal }\end{array}$ & C.C. & $\mathbf{0 . 1 1 8}$ & NS & $\mathbf{0 . 0 1 4}$ & NS \\
\hline & P-value & $\mathbf{0 . 2 1 2}$ & & $\mathbf{0 . 8 8 6}$ & \\
\hline
\end{tabular}

${ }^{(*)}$ S:Sig. at P<0.05; NS: Non Sig. at P>0.05; Test Statistics are based on Contingency Coeff. test. 


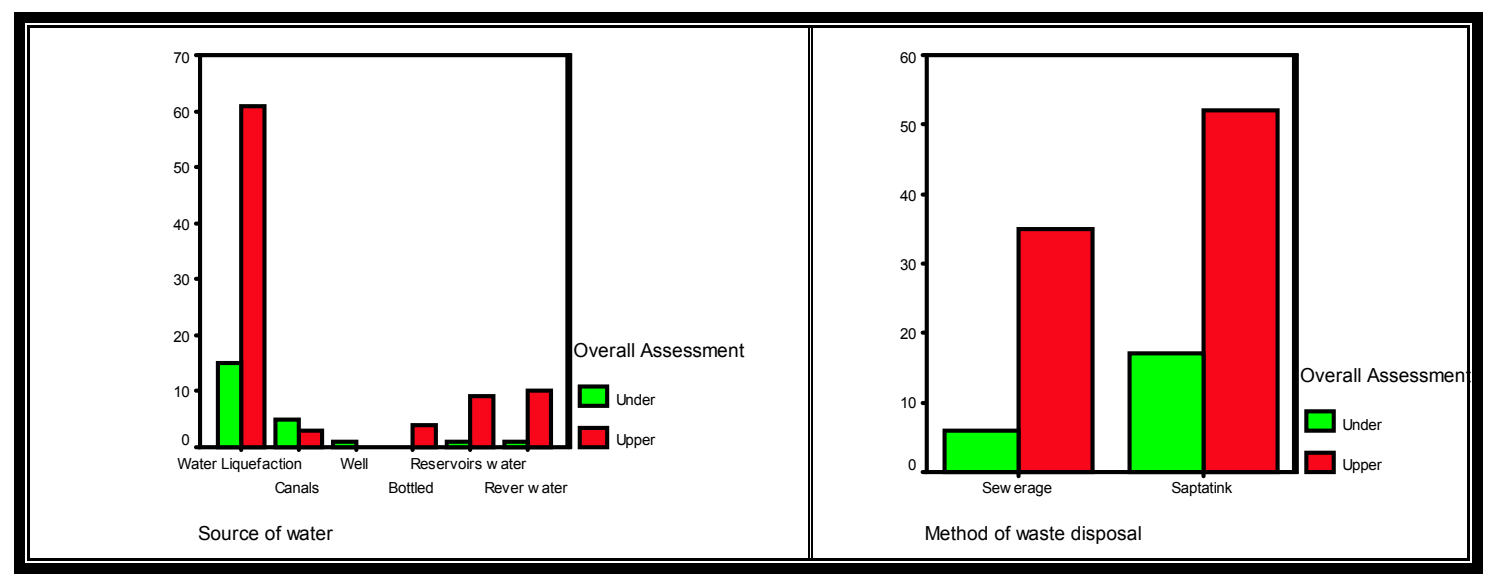

Figure (4-4): Bar charts for studied association between (knowledge \& attitudes)

\section{in light of related general information variables.}

\section{Discussion:}

Knowledge meaning what is known, attitudes meaning what is thought about general and/or specific topics particular population, these topics would include Cholera definition, mode of transmissions,sings of disease, cholera diagnosis, costive agent of disease, infect cholera, treatment, the most important complications of the disease, what are the most important things to be observed for the traveler to affected areas should be, increasing susceptibility, asking about the most roads contribute to transmission of the disease, and finally attitudes for Cholera disease. Information was collected by interview through a structured, standardized questionnaire that include qualitative data.

Knowledge was defined by Homby [7] as a state of knowing about a particular fact or situation. In order to mange Cholera and prevent reoccurrence, transmitted, causality, treatment, minimizing the spread. In terms of the number of cases, South East Asia carries the biggest burden of disease, and in our country cholera also remained main problem, since many

studies show this real, so that it needs to increases knowledge. Attitudes of people especially people with indigence ( low socioeconomic status).Through the course of the data analysis, the highest percentage for knowledge about mode of transmission was for drinking contaminated water with human excreta containing the microbe about $(80.9 \%)$, and this result are in agreement with Almagro, and others (2015)[8]. Azman and others (2012) [9] were finding that most signs of cholera shows highest percentage in lighted bloody diarrhea with severe cramps about $(72.7 \%)$, and our study are recorded a moderate degree $(59.6 \%)$ according to assess of studied sample concerning knowledge of sings of disease and this are almost in agreement, since they are indicated the same level of assessment according to the measuring scale's intervals. Health and nutrition sector outcome team (HNSOT), (2008) [10], finding that costive agent of disease was $(68.2 \%)$, and our study are recorded a moderate degree $(64.0 \%)$ for assess studied sample for the knowledge concerning causative agent of disease, and this are identical in agreement. For a knowledge concerning main domain, of asking about how can prevention of Cholera, which shows that $(67.0 \%)$, of the studied people who are answered that could be prevented cholera by "Boiling 
water", and that arein agreement with A.H. Dotyin [11].

With respect to knowledge concerning infect Cholera,our study are recorded high degree $(40.1 \%)$, especially for who areanswered item which says that cholera is infect both of them (children \& elderly), are disagreement with SM. Albert, MJ; Mekalanos, JJ [12], since there outcomes are achieved to $(90.0 \%)$.

Regarding to knowledge main domain of asking about treatment,as well as for themost important complications of cholera, $(63.8 \%)$ of people who answered that treatment of cholera is give some antibiotics sometimes along with lotions and liquids such as tetracycline capsules, and this are in agreement with WHO. 2010 [13]. Regarding to subject of people's knowledge concerning Cholera, and for the most important complications of disease, result recorded highest percentage for answered death and they are accounted (66.1\%), and this are in agreement with WHO. 2010 [14]. For a knowledge concerning main domain, of asking about how can prevention of Cholera, which shows that $(67.0 \%)$, of the studied people who are answered that could be prevented cholera by "Boiling water", or increase the proportion of chlorine in the water, and this are in agreement with A.H. Dotyin [15].

With respect to knowledge concerning main domain of asking, what are the most important things to be observed for the traveler to affected areas should, $(58.6 \%)$ of people who are answered positively, and this are in agreement with SM. Albert, MJ; Mekalanos, JJ [16].

For a knowledge concerning main domain, of asking about what do you think, most roads contribute to the transmission of the disease Cholera?, results shows that $(54.1 \%)$, of the studied people who are answered positively, and this in agreement with A.H. Dotyin [17].
Finally, with respect to attitudes for Cholera disease(93.3\%), of the people who are answered positively, and this are in disagreement with SM. Albert, MJ; Mekalanos, JJ [18], since they are accounted $(89.0 \%)$.

\section{Conclusion}

and

\section{Recommendations:}

\subsection{Conclusion:}

1.Vast majority of studied sample had consumption of Liquefaction water, and most of them are used dejection tank"Sabtatink " at their houses.

2. Most of the studied items concerning knowledge main domain for cholera disease in light of sub domains contents had reported moderate assessments, as well as most of the studied persons had good attitudes concerning cholera disease, which could be interpreting hereditary of life style standby creation high level of attitudes.

3.Result showed that studied questionnaire of studying "Factors of knowledge, and attitude" could be amended for studied population rather than a differences with their socio-economic status, since no significant differences are accounted in relationships with their knowledge and attitudes assessments.

4.Studied responding concerning knowledge, and attitudes regarding to general information variables, such that (Sources of water, and Methods of waste disposal) had weak relationships, except with the distribution of source of water, which representative that individuals of consumption water of "Liquefaction" source are accounted better responding than other consumption's sources.

\subsection{Recommendation:}

1.There is great needs to assess the quality of knowledge and attitudes of people regarding cholera infection, and that means necessity of applying this survey's research continuously. 
2.Well health education for the community via all mass media concerning risk factors and communicability of this disease is important.

\section{References :}

1.Benson AS. Cholera. In: Evans AS, Brachman PS, eds. Bacterial infection of humans: epidemiology and control, 2nd ed. New York, Plenum: 207-25, 1991.

2.Cholera 1996. Weekly epidemiological record; 72(31):229-35, 1997.

3.Singh $\mathrm{J}$ et al. Endemic cholera in Delhi, 1995: analysis of data from a sentinel centre. Journal of diarrhoeal diseases research; 16(2):66-73, 1998.

4.Cholera epidemic. In: Al-Wardi A. Lamahat Ijtima'iyya min Ta'rikh al-'Iraq al-Hadith (Social aspects of Iraqi modern history). Baghdad, Matba'a alAdib al-Baghdadiyya: 244-5, 1969.

5.Prepared for the Independent Advisory Group on Country Information (IAGCI) by Dr Alan George (King's College, University of London), "Review of Iraq: humanitarian situation in Baghdad, the south (including Babil) and the Kurdistan Region of Iraq, issued in June 2015 and republished in July 2015".

6.Al-Naqeeb Abdulkhaleq A., 2007, "Suggested Technique for estimation of relative smoothed grade for contaminated data in spectral analysis by using Robust General Maximum Likelihood methods of Al- Naqeeb and Thomson", Al Rafedian Scientific Journal- Iraq.

7.pdate: Cholera outbreak-Haiti, 2010. MMWR Morb Mortal Wkly Rep. 2010;59:1473-9.

8.Wong W, Ho YY. Imported cholera cases among tours returning from Thailand. Public Health \& Epidemiology Bulletin 1998;7(3):21-4.
9.Homby A. S. (2006); Oxford Advanaced Learner's Diction, $6^{\text {th }}$ Edition, Oxfored University Press, New York.

10.Almagro-Moreno, S; Pruss, K; Taylor, RK (May 2015). "Intestinal Colonization Dynamics of Vibrio cholera.". PLoS pathogens 11 (5): e1004787. PMID 25996593.

11.Sack DA, Sack RB, Nair GB, Siddique AK (January 2004). "Cholera". Lancet 363 (9404): 223-33. doi:10.1016/S0140-6736(03)15328-7. PMID 14738797.

12.Health and Nutrition Sector Outcome Team (HNSOT)(2008). Situation Report on Diarrhea and Cholera in Iraq 17 September 2008.

13.Cholera Fact Sheet", World Health Organization. WHO.int. Retrieved November 5, 2013.

14.Faruque, SM; Albert, MJ; Mekalanos, JJ (Dec 1998). "Epidemiology, genetics, and ecology of toxigenic Vibrio cholerae.". Microbiology and molecular biology reviews : MMBR 62 (4): 130114. PMC 98947. PMID 9841673.

15.WHO report, Oral Rehydration Solutions: Made at Home. The Mother and Child Health and Education Trust. 2010. Retrieved 2010-10-29.

16.Asimov, Isaac (1982), Asimov's Biographical Encyclopedia of Science and Technology (2nd rev. ed.), Doubleday.

17.Hasson S. O., Al-Khafagi Z. A . and Hendi N. K. 2012. Study of Vibrio Cholerae 18.Huq, A., R. R. Colwell, M. A. Chowdhury, B. Xu, S. M. Moniruzzaman, M. S. Islam, M.Yunus, and M. J. Albert. 1995. Coexistence of Vibrio cholerae O1 and O139 Bengal in plankton in Bangladesh. Lancet 345:1249. 


\section{دراسة مسحية بالعينة حول معارف واتجاهات مرض الكوليرا للمقيمين في سوق الثيون}

محمد عيسى عبد الستار الوشاح

عبد الخالق عبد الجبار علي غالب النقيب

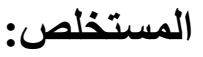

يهرف البحث الحالي الى التعرف على مستوى معارف و اتجاهات سكان منطقة سوق الثيوخ

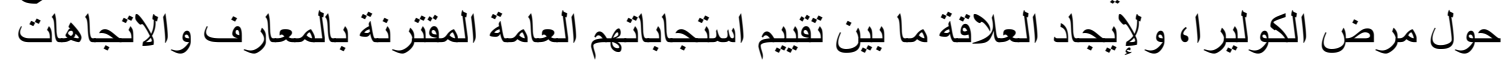

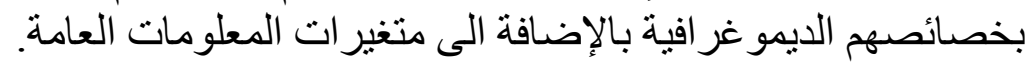

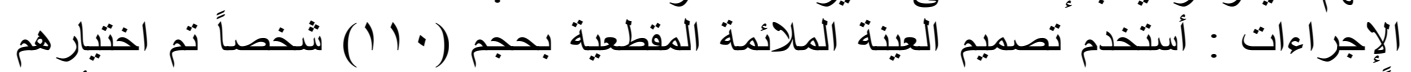

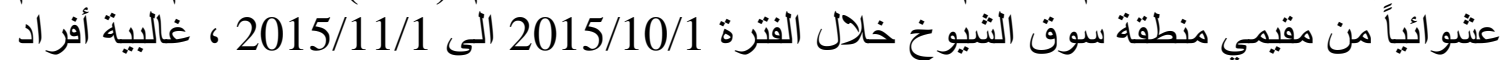

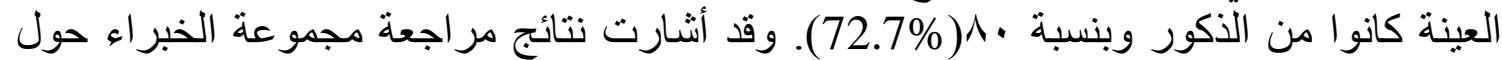

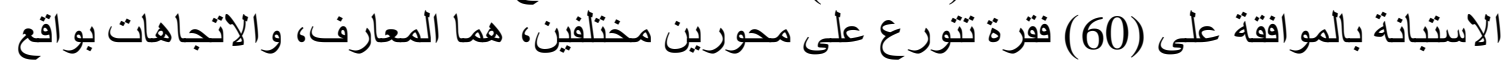

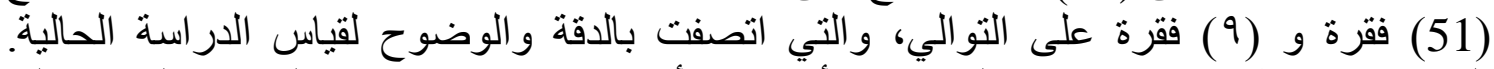

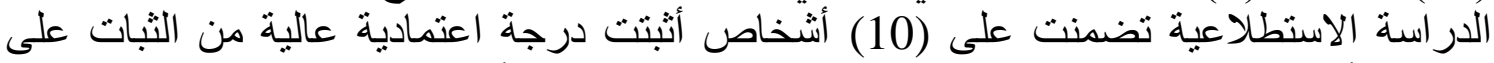

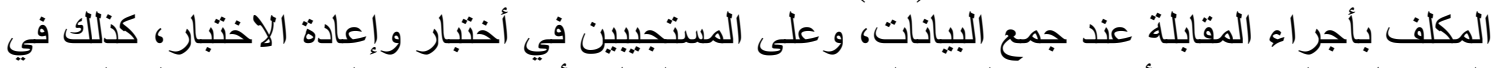

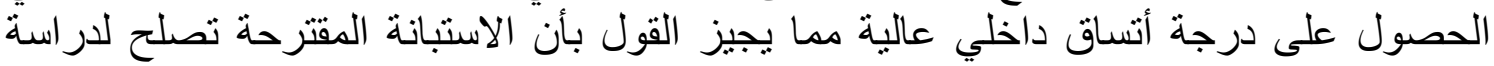

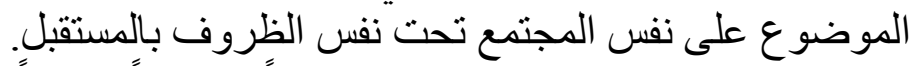

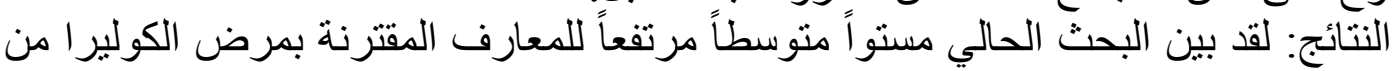

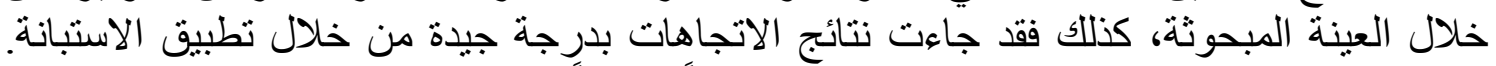

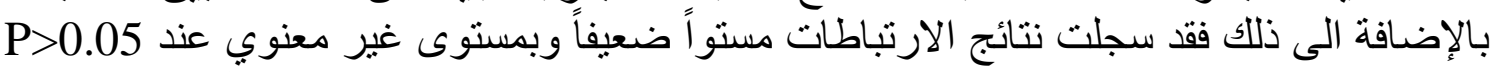

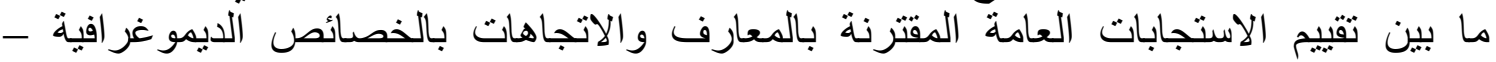

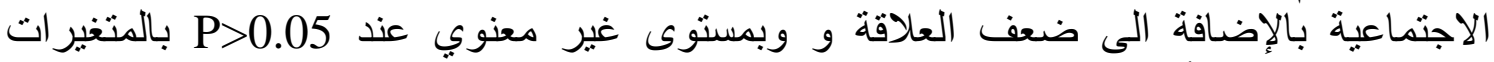

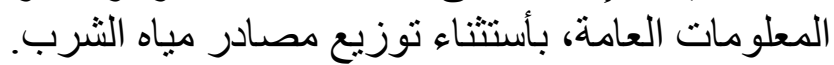

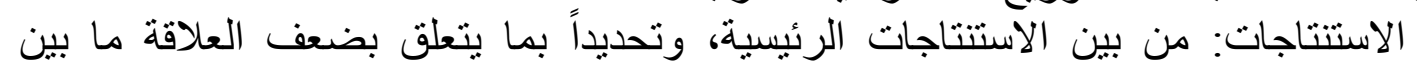

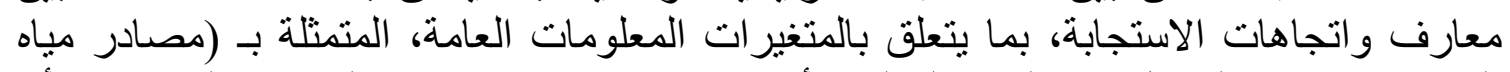

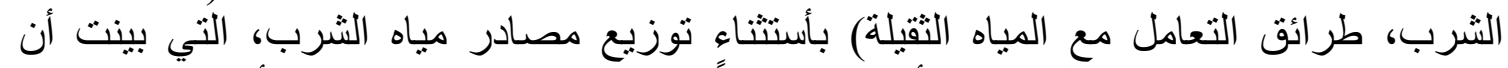

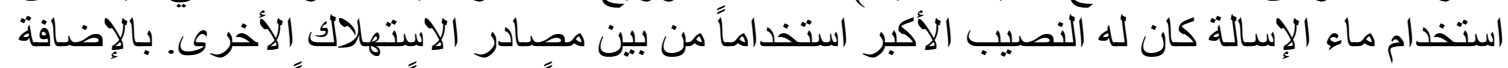

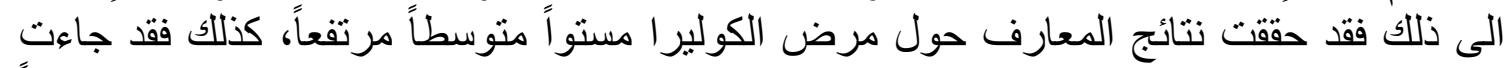

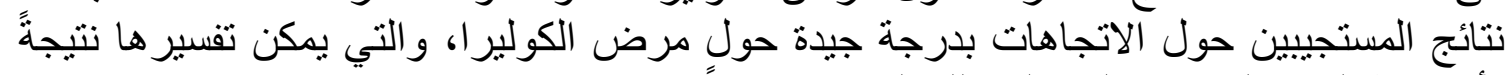

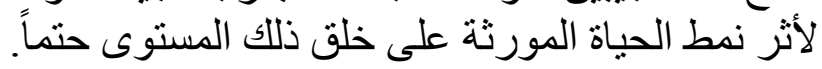

